\title{
Territorial differentiation of public sentiment in modern Georgia (the experience of sociological survey)
}

\author{
M. N. Shestakova ${ }^{1}$
}

1MGIMO University, 76 Vernadsky Ave., Moscow 119454, Russian Federation

DOI: $10.18255 / 2412-6519-2021-2-146-157$

Research Article

Full text in Russian

At the end of October 2020, parliamentary elections took place in Georgia. Another electoral cycle has started. What will it bring in terms of bilateral relations between Russia and Georgia? After the end of the election campaign, a sociological survey was conducted among residents of the neighboring state in order to clarify their attitude towards Russia, its potential impact on the election campaign, and possible ways of developing relations between the two states. Based on the results of the survey, the author finds out whether there is a territorial differentiation of public opinion on these issues. Is it possible to identify the "neighborhood effect" in relation to Russia? The research paper is an integral part of a large multi-year project, which studies the probable transformation of the electoral behavior of residents of the states bordering Russia. The author comes to the conclusion that despite the existing considerable political contradictions between the two states, there is a great potential for good neighborhood relations, expressed in the prevailing positive public opinion regarding the neighboring state. The regions of Georgia bordering Russia do not demonstrates any particular loyalty. It was possible to identify territorial differences in public opinion along the North-South line, which require additional research.

Keywords: Georgia; Russian Federation; parliamentary elections; Russian-Georgian relations; public opinion poll; territorial differentiation

INFORMATION ABOUT THE AUTHORS

\begin{tabular}{r|l} 
Shestakova, Marianna N. & E-mail: m.shestakova@my.mgimo.ru \\
(correspondence author) & Cand. Sc. (Geography)
\end{tabular}

Funding: Russian Science Foundation, Project No. 19- 78-10004 "Transformation of Electoral Behavior in the Regions of Foreign Countries Bordering the Russian Federation: Comparative Spatial Analysis".

For citation: Shestakova M. N. Territorial differentiation of public sentiment in modern Georgia (the experience of sociological survey) // Social'nye i gumanitarnye znanija. 2021. Vol. 7, No 2. P. 146-157. (in Russ.)

(C) Shestakova M. N., 2021

This is an open access article under the CC BY license (https://creativecommons.org/licenses/by/4.0/) 


\title{
Территориальная дифференциация общественных настроений в современной Грузии (опыт социологического опроса)
}

\author{
М. Н. Шестакова ${ }^{1}$
}

1МГИМО МИД России, пр. Вернадского, 76, Москва, 119454, Российская Федерация

DOI: $10.18255 / 2412-6519-2021-2-146-157$

удК 32.019 .52

Научная статья

Полный текст на русском языке

В конце октября 2020 г. в Грузии состоялись парламентские выборы. Стартовал очередной электоральный цикл. Что принесёт он в плане взаимоотношений России и Грузии? После окончания избирательной кампании был проведён социологический опрос среди жителей соседнего государства с целью выяснения их отношения к России, её потенциального влияния на избирательную кампанию, возможных путей развития взаимосвязей двух государств. Опираясь на результаты анкетирования, автор исследует наличие территориальной дифференциации общественного мнения по данным вопросам. Возможно ли выявить «эффект соседства» по отношению к России? Исследование является составной частью большого многолетнего проекта по изучению вероятной трансформации электорального поведения жителей пограничных с Россией государств. Автор приходит к выводу, что, несмотря на довольно серьезные политические противоречия между двумя государствами, существует большой потенциал добрососедских отношений, выражающийся в преобладающем позитивном общественном мнении по отношению к соседнему государству. Приграничные с Россией регионы Грузии не проявляют какой-либо особой лояльности. В работе также выявлены территориальные различия в общественном мнении по линии Север - Юг, которые требуют дополнительного исследования.

Ключевые слова: Грузия; Российская Федерация; парламентские выборы; российскогрузинские отношения; опрос общественного мнения; территориальная дифференциация

ИНФОРМАЦИЯ ОБ АВТОРАХ

Шестакова, Марианна Николаевна $\mid$ E-mail: m.shestakova@my.mgimo.ru

(автор для корреспонденции)

Финансирование: РНФ, грант № 19-78-10004 «Трансформации электорального поведения в регионах зарубежных стран, пограничных с Российской Федерацией: сравнительный пространственный анализ», реализуемый научным коллективом МГИМО МИД России.

Для цитирования: Шестакова М. Н. Территориальная дифференциация общественных настроений в современной Грузии (опыт социологического опроса) // Социальные и гуманитарные знания. 2021. Том 7, № 2. С. 146-157.

\section{Введение}

Начиная с весны 1989 г. и до последнего времени отношения между Россией и Грузией остаются достаточно сложными. Весомое противоречие, не позволяющее говорить о взаимном доверии в ближайшей и отдаленной перспективе, - это призна-

(C) Шестакова М. Н., 2021

Статья открытого доступа под лицензией СС BY (https://creativecommons.org/licenses/by/4.0/) 
ние Россией двух бывших регионов Грузии, Абхазии и Южной Осетии, в качестве независимых государств после событий 2008 г. Тем не менее время затягивает даже самые глубокие раны, и зачастую прагматический подход и здравый расчёт берут верх над сильными, неизлечимыми обидами и эмоциями. В течение последнего десятилетия отношения, казалось бы, сдвинулись с точки «невозврата» и даже стали демонстрировать постепенную положительную динамику, перечёркнутую, однако, событиями 2019 г., когда в очередной раз было прервано авиасообщение, сократился товарообмен и снизился туристический поток. При этом сознательно не берётся в расчет объективный «пандемический спад» 2020 г., который негативно повлиял на всю мировую экономику, на отношения всех со всеми и отголоски которого будут ощущаться ещё в течение продолжительного времени.

В 2013 г. Грузия стала парламентской республикой, и на протяжении двух электоральных циклов взаимоотношения между Россией и Грузией стали постепенно налаживаться, внушая осторожный оптимизм. Несмотря на диаметрально разные позиции по поводу Абхазии и Южной Осетии (рассматриваемые Грузией как «оккупированные территории»: «Автономная Республика Абхазия» и «Цхинвальский регион») и, как следствие, до сих пор невосстановленные дипломатические отношения, сторонам по ряду вопросов удаётся вести переговоры. В первую очередь это касается экономической и социальной сфер: «на российский капитал приходится значительная доля прямых зарубежных инвестиций в экономику Грузии» $[1$, с. 82]. Вопрос об активизации политического диалога остаётся открытым [Там же. С. 84] при сохранении российско-грузинского конфликта, который, по утверждению А. М. Понамарёвой, «преподносится как конфликт ценностный, часть более широкого фронта борьбы Запада с авторитарными недемократическими политиями» [2, с. 118].

Скорее всего, не улучшит политический климат между государствами и недавнее решение ЕСПЧ (21 января 2021 г.) по иску Грузии к России по правам человека, которое каждая из сторон сочла своей победой [3]. По убеждению В. М. Муханова, «позиции сторон по ряду вопросов, включая оценку событий 2008 г., диаметрально противоположны ... Единственное, что может повлиять на улучшение ситуации, это только время» [4]. Грузия не скрывает своей «прозападной» направленности и последовательного движения в сторону членства в Евросоюзе и НАТО. Можно утверждать, что идея европейской интеграции страны, возвращения её в Европу для грузинского общества не нова. По словам Н. Ю. Силаева, «Россия была ценна для Грузии постольку, поскольку способствовала такому возвращению, например, давала доступ к университетскому образованию» [5, с. 106].

Вначале коалиция, а потом и правящая «монолитная партия» [6] «Грузинская мечта», которая уже трижды побеждала на выборах в республиканский парламент («первый случай в постсоветской истории Грузии, когда партия власти выигрывает третий раз кряду») [7] в 2020 г., не собирается менять данный внешнеполитический курс, сочетая его с попыткой нормализации российско-грузинских отношений. При этом практически вся нынешняя оппозиция, прошедшая в парламент (но не планирующая пока повышать его легитимность своим присутствием), также в большинстве своём ориентируется на европейских и американских партнёров. По мнению Н. Ю. Силаева, выраженному по итогам выборов 2016 г., «в условиях, когда внешнеполитическая программа большинства партий практически одинакова, избиратели не склонны разбираться в деталях политической позиции мелких либеральных партий, отдавая предпочтение мейнстриму» [8, с. 8]. Данный вывод не утратил своей актуальности и в нынешнем электоральном цикле. 
Справедливости ради следует отметить и тот факт, что Грузия также вполне адекватно выстраивает отношения с соседними государствами: прежде всего с Турцией, Арменией и Азербайджаном. Очень часто в дискурсе противопоставляют ориентацию на «коллективный Запад» (США, НАТО, ЕС) и пророссийскую позицию как два ключевых противовеса, при этом не беря в расчёт соседей и региональных акторов. И хотя Грузия является, пожалуй, единственной в регионе страной, планомерно стремящейся к евро-атлантической интеграции, тем не менее она старается выстраивать многовекторные взаимоотношения с соседними государствами: «Экономические реалии заставляют её разворачиваться на юг и на север» [9, с. 58].

Безусловно, почти половина голосов пришедших на выборы избирателей, отданных за «Грузинскую мечту», достаточно убедительна, чтобы считать, что граждане, точно так же, как и политики, безоговорочно придерживаются «прозападного» курса, впрочем, как и большинство оппозиционеров, а некоторые из них при этом имеют и ярко выраженный антироссийский настрой. Опросы, проходящие в стране, показывают достаточно высокий уровень поддержки выбранного властями внешнеполитического курса. По различным данным, «около 80 \% населения выступают за членство страны в НАТО и в Евросоюзе» [10]. Т. 3. Мансуров приводит результаты исследования Международного республиканского института Грузии, который проводился в 2015 г. и согласно которому «76 \% респондентов считают Россию угрозой и только 18 \% партнером» $[11$, с. 35]. Хотя в этом же опросе «весьма оптимистичным выглядит стремление грузин развивать взаимоотношения с Россией» [Там же]. На последнее указывают и другие авторы: исследования общественного мнения с учётом прозападного курса «демонстрируют важность добрососедских отношений с Россией» [12, с. 88].

Вызывает интерес ответ на вопрос, подтверждается ли представленный тезис в настоящее время: каково отношение жителей страны к самому крупному и ещё не так давно «родному» соседу. Имеет ли место территориальная дифференциация этого отношения или все регионы демонстрируют одинаковые показатели?

\section{Методы}

После того, как 31 октября 2020 г. прошли выборы в парламент Грузииㅜㄹ, по заказу исследовательской группы ${ }^{2}$ был проведён социологический опрос жителей республики на предмет их отношения и проявления интереса к России, возможного влияния соседнего государства на избирательную кампанию, потенциального воздействия соседей на электоральное поведение. Данный соцопрос являлся очередным этапом изучения стран - соседей Российской Федерации в рамках большого многолетнего исследования, призванного изучить феномен влияния «соседства» государства на электоральное поведение граждан сопредельных стран. Социологический опрос состоялся в формате телефонного анкетирования, в ходе которого было совершено более 6000 звонков, ответили 2000 человек, было получено 500 полноценных анкет. Опрос проходил в столице государства, в девяти краях и одной автономной республике. На рис. 1 представлено современное административно-территориальное деление Грузии ${ }^{3}$.

\footnotetext{
${ }^{1}$ Формально избирательная кампания ещё не была завершена, поскольку выборы проходили по смешанной системе и в части одномандатных округов 21 ноября состоялся второй тур.

${ }^{2}$ Исследовательская группа научного коллектива МГИМО МИД России, куда входит и автор настоящей статьи.

${ }^{3}$ Современное административно-территориальное деление дано с учетом выделения Абхазии и Южной Осетии в качестве независимых государств, на территории которых исследование не проводилось.
} 


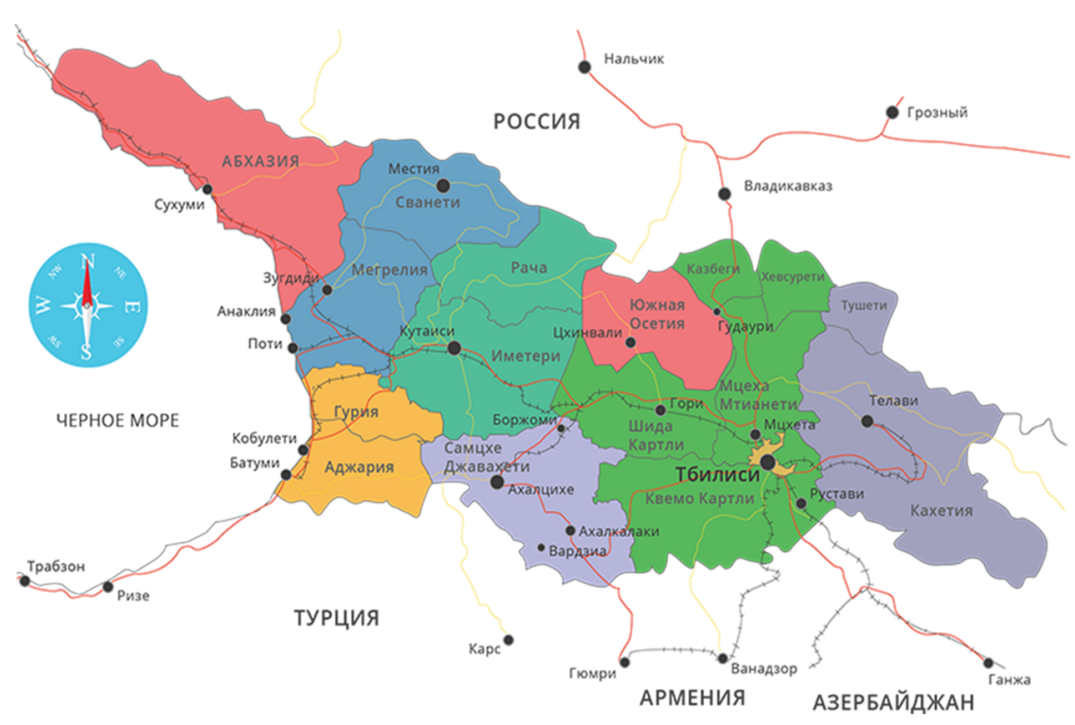

Рисунок 1. Административно-территориальное деление Грузии ${ }^{1}$.

При этом было соблюдено относительно равномерное распределение в территориальном разрезе среди населения с фиксацией возраста, пола и национальности. Социальное положение, образование, доход были вне рамок анкетирования. Поскольку сбор данных был проведён среди абонентов стационарных телефонов, то больше всего анкет было получено в Тбилиси, минимальное число полноценных анкет - в регионах горной местности: Рача-Лечхуми и Квемо-Сванети, Самегрело и Земо-Сванети (самый малонаселённый край Нижнюю Сванетию пришлось технически соединить с Верхней Сванетией в один кластер), а также в Мцхета-Мтианети, Кахети, Имерети.

В соцопросе приняли участие 64 \% мужчин и $36 \%$ женщин (что, разумеется, не отражает реальное гендерное соотношение в республике: по переписи населения, проведённой в 2014 г., данный показатель составлял 47,7 и 52,3\% соответственно) [13]. При этом по регионам по данному параметру велики диспропорции: так, в Гурии, Кахети и Шида-Картли доля женщин, участвовавших в соцопросе, составила всего от 10 до 20 \% интервьюируемых. В Тбилиси и Аджарии удельный вес женщин, принимавших участие в анкетировании, напротив, достигает более половины (58\% и 56 \% соответственно). Такие несоответствия по полу респондентов в реальной ситуации вполне объяснимы тем, что жанр телефонного опроса на тему политики предполагает большую вовлечённость в такие сюжеты традиционно мужского населения, особенно в регионах, где в большинстве своём все ещё сохраняется патриархальный уклад.

Что касается возраста респондентов, то предсказуемо мало для такого вида опроса молодёжи от 18 до 25 лет - лишь 4 \%, более половины опрашиваемых от 35 до 55 лет, пожилых людей старше 65 лет - каждый десятый (согласно последней переписи населения таковых в стране 14 \%) [13]. Самому молодому участнику -

\footnotetext{
${ }^{1}$ Карта взята с сайта https://allgeotrip.ru/stati/karta-gruzii (дата обращения: 10.02.2021).
} 
19 лет, самому пожилому - 80 лет. Анкетирование проводилось на русском языке, который раньше «изучался в школах практически наравне с грузинским» [14, с. 104] и на котором, по утверждению ряда авторов, свободно говорит «старшее поколение Грузии» [Там же]. Опрос на русском наложил ограничения на выборку и, вероятно, частично повлиял на выбор ответов респондентов. Однако, поскольку, по убеждению ряда экспертов, русский язык «продолжает сохранять в Грузии стабильные позиции как язык межнационального и лингвогосударственного общения» [15, с. 139] и владение им «укорачивает путь к диалогу по нормализации грузино-российских отношений» [16, с. 130], мы сочли возможным считать релевантными значения данного опроса.

Подавляющее число интервьюируемых - 86 \% - грузинской национальности, 4,5 \% - армяне, 3,7 \% - русские, 2 \% - азербайджанцы, на остальные национальности приходится менее 5 \%. Доля грузин и армян, принимавших участие в опросе, соответствует показателям переписи в 2014 г. [13], удельный вес азербайджанцев и русских не совпадает. Что касается распределения национальностей по регионам, то практически только грузины приняли участие в опросе в Рача-Лечхуми и Квемо-Сванети Самегрело и Земо-Сванети (98\%), Тбилиси (97\%), Шида-Картли (94 \%) (эти данные коррелируются с переписью 2014 г.). Меньше всего грузин в Аджарии (76 \%), КвемоКартли (70 \%), Самцхе-Джавахети (68 \%). Последние два края - ареалы традиционного проживания азербайджанцев и армян на территории Грузии. Но в анкетировании приняли участие меньше граждан данных национальностей, нежели их зафиксировано в последней переписи: «В Квемо-Картли доля азербайджанцев составляет 41,8 \%, армян - 5,1 \%. В Самцхе-Джавахети 50,5 \% населения составляют армяне» $[17$, c. 110$]$. В опросе же приняли участие в Квемо-Картли $14 \%$ азербайджанцев и $4 \%$ армян; в Самцхе-Джавахети - 24 \% армян и $2 \%$ азербайджанцев. Необходимо заметить, что в постсоветской Грузии некогда политэтничный Тбилиси превратился практически в моноэтничный, а основная тенденция в условиях уменьшения численности населения - увеличение доли грузин в стране [Там же. С. 106].

\section{Результаты}

Достаточно непростые взаимоотношения государств сыграли свою роль, и на вопрос: «Как часто Вы бываете в России?», почти 1/3 населения ответили, что никогда не были в соседней стране. Больше всего таких граждан проживает в РачаЛечхуми и Квемо-Сванети - Самегрело и Земо-Сванети и Тбилиси (47,6 и 42,2 \% соответственно), меньше всего - 15,9\% - в пограничном с Россией Мцхета-Мтианети. Ничтожно мала доля тех, кто регулярно посещает Россию (раз в год и чаще), - менее 5 \%. В основном в стране больше всего тех, кто изредка бывает в России (реже одного раза в год). Таких почти $2 / 3$.

Каждый 10-й опрошенный не интересуется новостями из России, больше всего в столице (почти каждый 5-й), меньше всего (4,1\%) - в Квемо-Картли. Почти половина всех опрошенных узнает новости о соседней стране из интернета (49,5 \%), почти 1/3 из российских СМИ. Больше всего тех, кто обращается к российским СМИ с целью узнать новости из соседнего государства, в Аджарии и Мцхета-Мтианети (38 и 40,9 \%), меньше всего (что вполне объяснимо) - в Тбилиси $(24,2$ \%), в Рача-Лечхуми и КвемоСванети - Самегрело и Земо-Сванети $(21,4 \%)$. В последнем регионе жители узнают новости из интернета (69\%). Из местных средств массовой информации получают 
сведения о России менее 8 \%, больше всего в Кахети $(17,5$ \%), в Имерети $(2,9 \%)$ и таковых не оказалось в Рача-Лечхуми и Квемо-Сванети - Самегрело и Земо-Сванети.

Поскольку опрос проходил сразу после парламентских выборов, то ряд вопросов был посвящён прошедшей избирательной кампании. Лишь 13,6 \% респондентов считают, что в ходе последней кампании много обсуждались отношения с Россией. Почти 60 \% утверждают, что взаимоотношения с Россией не были в фокусе внимания. При этом 45,3 \% интервьюируемых полагают, что отношения с Россией должны быть одной из важных тем политической кампании (в Имерети - более $57 \%$ ), четверть придерживаются противоположного мнения (треть - в Рача-Лечхуми и Квемо-Сванети - Самегрело и Земо-Сванети), 30 \% не имеют мнения на этот счёт.

На вопрос: «Менялось ли Ваше отношение к кандидату, если в ходе избирательной кампании он делал акцент на взаимоотношения с Россией?» - в целом по стране 38,5 \% ответили, что это повышало симпатии избирателей, причём в таких регионах, как Гурия, Самцхе-Джавахети и Шида-Картли их почти половина. Меньше всего положительно ответили на этот вопрос жители столицы $(27,5 \%)$ и Мцхета-Мтианети $\left(29,5\right.$ \%). На рис. $2^{1}$ представлены данные среднего квадратичного отклонения по вопросу об увеличении симпатии к кандидатам, делающим акцент в избирательной кампании на развитие отношений с Россией.

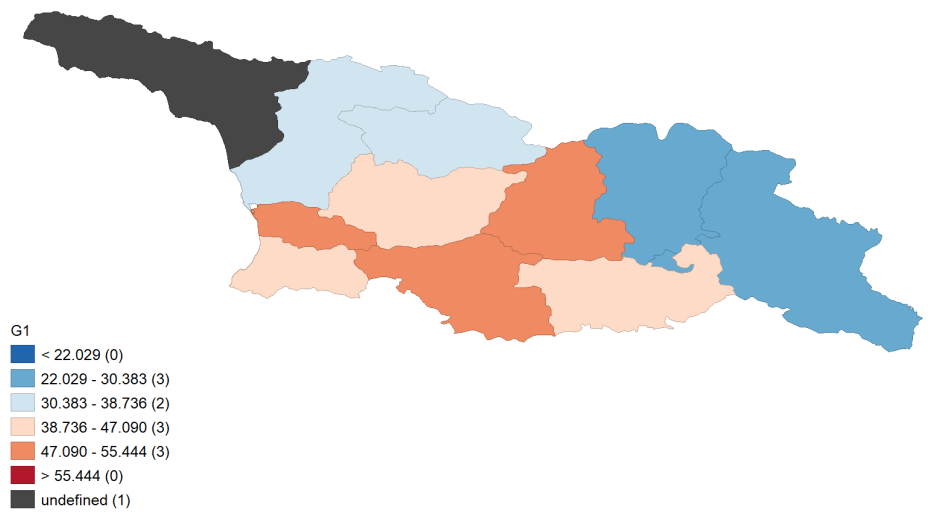

Рисунок 2. Территориальная дифференциация регионов Грузии по отношению к кандидатам, делающим акцент на развитие отношений с Россией.

\footnotetext{
${ }^{1}$ Для построения картограмм был использован векторный слой международной открытой базы данных по административным границам стран мира (GADM, Database of Global Administrative Areas), распространяемый по лицензии, допускающей свободное использование данных в исследовательских целях (https:/gadm.org/license.html). Данный слой фиксирует международно признанные границы, поэтому территории Абхазии (без цвета) и Южной Осетии (не выделена цветом) показаны на карте Грузии, что не отражает политическую позицию автора.
} 
В среднем по Грузии доля тех, для кого упор на развитие отношений с Россией снижал симпатию к кандидату, составляла 7,8 \%, минимальный удельный вес таких респондентов наблюдался в Шида-Картли (2\%) и Мцхета-Мтианети (4,5\%), больше всего их было в Аджарии и Тбилиси (14 и 13,2 \% соответственно). На более чем половину интервьюируемых акцент кандидата в избирательной кампании на взаимоотношения с Россией никак не влиял на восприятие самого кандидата.

Российское влияние на избирательную кампанию ощутили 17 \% из числа опрошенных (максимально - в Рача-Лечхуми и Квемо-Сванети - Самегрело и Земо-Сванети $(21,4$ \%), минимально - в Гурии $(10,2$ \%)). Не заметили «русский след» каждый третий $(34,5 \%)$, почти половина (48,5\%) респондентов затруднились ответить на данный вопрос.

Ещё два важных вопроса, которые интересовали интервьюеров: формат отношений жителей Грузии к северному соседу и Евросоюзу. Поскольку Европейский союз и Грузия в 2014 г. уже подписали соглашение об ассоциации, а с начала 2017 г. действует безвизовый въезд с краткосрочным визитом в страны Шенгена, для жителей республики вопрос взаимоотношений с Евросоюзом не является некоей абстракцией (хотя до реального членства ещё далеко). Респондентам были предложены четыре варианта ответа: союзнические, партнерские, нейтральные и враждебные, на вопрос, какой из этих форматов наиболее предпочтителен. Неожиданностью было получить в среднем по стране 42,5 \% респондентов, желающих союзнических отношений с Российской Федерацией. А в Кахети, Гурии и Самцхе-Джавахети так отвечал каждый второй $(52,5$, 49,0 и $48 \%$ соответственно). И если в последнем из перечисленных регионов велика доля этнических армян, всегда с симпатией относящихся к России (хотя в нашем опросе принимало меньше армян, чем живёт в крае), то в Кахети и Гурии на вопросы отвечали в основном грузины (87,5 и 92 \% соответственно). На рис. 3 обращает на себя внимание объединение в одну группу регионов, которые ряд авторов выделяет как «один целостный регион» [18, с. 224]: Квемо Картли и Шида Картли, Самцхе-Джавахети и Гурия.

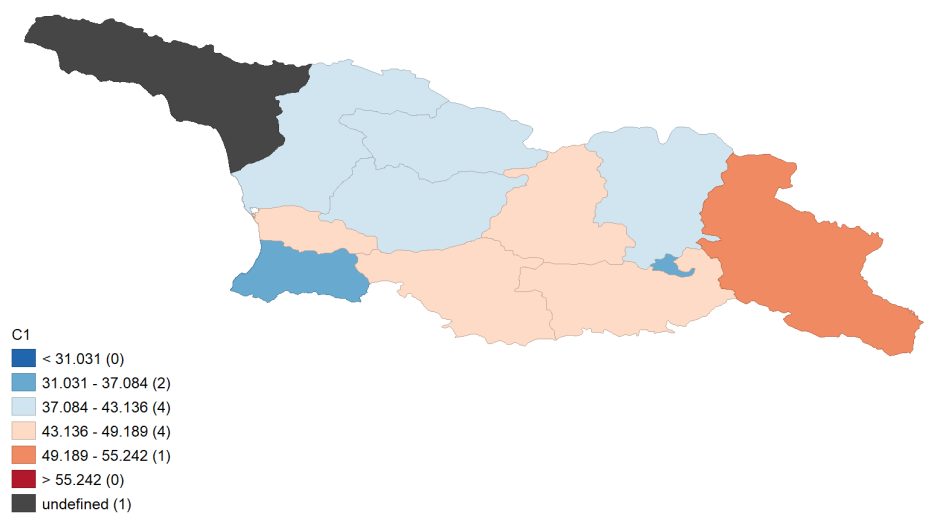

Рисунок 3. Удельный вес респондентов, выступающих за союзнические отношения с Россией. 
За партнёрские отношения с Россией выступили чуть более 30 \% по стране в целом, больше всего в Аджарии (40\%) и в Квемо Картли (38,8\%). Если сложить обе цифры, то видно, что за союзнические и партнёрские отношения с Россией (очевидно, стоит понимать, скорее, как «добрососедские») высказались 3/4 всех участвующих в опросе граждан.

Что касается нейтральной позиции, то её придерживаются 22,6 \% респондентов, больше всего - 37,4 \% - в Тбилиси, где предсказуемо меньше жителей, выступающих за союзнические отношения (33 \%) и партнёрские $(24,2 \%)$.

За враждебный формат отношений с Россией высказалось всего около 3 \% опрошенных. Больше всего таковых в столице и в Рача-Лечхуми и Квемо-Сванети Самегрело и Земо-Сванети, однако и в них эта цифра существенно ниже 10 \%.

На аналогичный вопрос про отношения с Евросоюзом были получены следующие ответы: в среднем по стране 28,1\% выступают за союзнические отношения; 42,3 \% - за партнёрские, 28,3 \% - за нейтральные (идентично по числу союзническим) и за враждебные - 1,2 \%. Если суммировать цифры за партнёрские и союзнические отношения с EC, то общий итог получается даже меньше $(70,4$ \%), чем за отношения с РФ. В среднем по Грузии данные представлены на рис. 4, отображающем соотношение голосов респондентов, отданных за разный формат взаимоотношений с Россией и Европейским союзом.

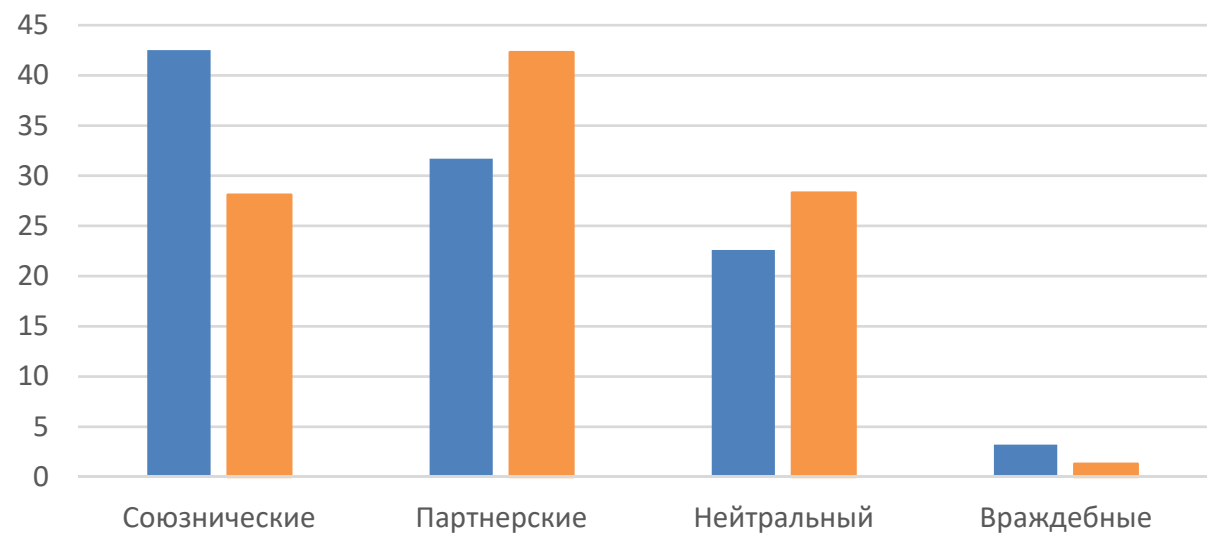

Какие отношения с Россией вы считаете наиболее приемлемыми? (ответы в \%) Какие оттношения с ЕС вы считаете наиболее приемлемыми? (ответы в \%)

Рисунок 4. Соотношение ответов респондентов за разные форматы взаимоотношений с Россией и Евросоюзом (в процентном отношении от всего количества ответов).

В разрезе территории здесь зеркальная картина, наблюдаемая по отношению к России: больше всего за союзнические отношения выступают опрошенные из Тбилиси и Аджарии - самые интегрированные в международную жизнь регионы (41,8 и 36 \% соответственно). Меньше всего - в Шида-Картли и Кахети (15,7 и 17,5 \%). В этих же регионах самый высокий процент тех, кто готов довольствоваться 
нейтральными отношениями с Европой (37,3 и 37,5 \% соответственно). На рис. 5 представлена территориальная дифференциация по вопросу относительно партнерских отношений с Евросоюзом.

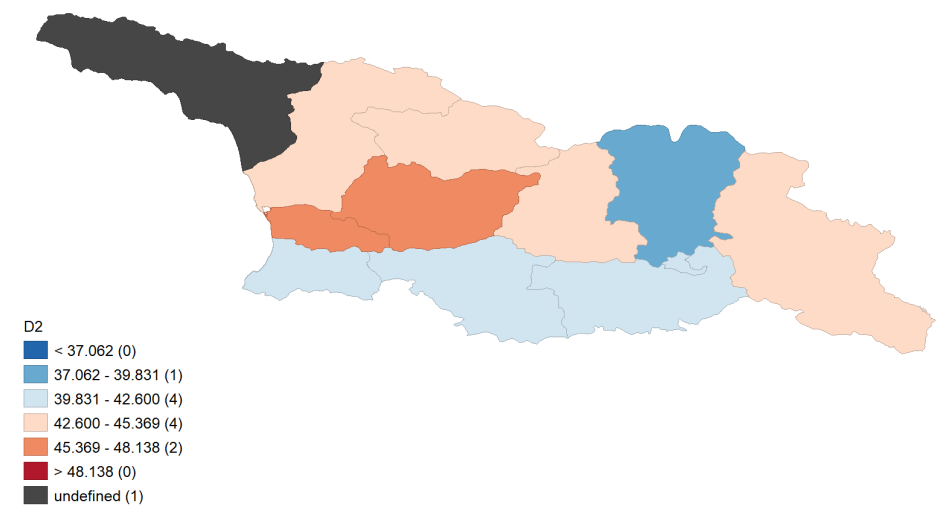

Рисунок 5. Удельный вес респондентов, выступающих за партнёрский формат отношений с Евросоюзом.

\section{Выводы}

По итогам опроса можно прийти к выводу, что, несмотря на очень серьезные разногласия, которые осложняют отношения между Россией и Грузией, существуют достаточно большие внутренние резервы для восстановления связей между соседями. По выражению С. М. Маркедонова, Россия для всего Кавказа останется «одним из главных гравитационных центров» [19, с. 117]. Для Грузии эти слова также вполне применимы.

Ответы на вопросы по поводу предпочтительного формата взаимоотношений с РФ расходятся с данными остальных опросов, а также общепринятым мнением об отторжении России и полной ориентации на Запад. Н. Ю.Силаев видит одну из причин стремительной утраты позиций России в Грузии в постсоветский период в том, что «потенциал российской “европейскости” был исчерпан в глазах грузинской элиты» [5, с.107]. Тем не менее подчеркнём, что, возможно, потенциал исчерпан для элиты и столицы, но не для жителей остальных регионов Грузии. Не секрет, что уровень жизни в регионах достаточно низок, социально-экономическая ситуация оставляет желать лучшего, особенно после пандемии 2020 г., и, вероятно, при ответах на вопросы респонденты (преимущественно среднего возраста) испытывали некоторую ностальгию по вполне благополучным временам позднего социализма. Поэтому нельзя не согласиться с Г. А. Гамкрелидзе, который считает, что «само культурно-историческое развитие Грузии, как и ее экономическая и политическая составляющие, тесно связаны с процессами, происходящими в России» [20, с. 136]. 
Как указывают многие исследователи, Грузия - «одна из самых мозаичных в отношении развития регионов страна» [21, с. 172]. На основе данной выборки мы не заметили территориальных расколов по линии Запад - Восток или Центр - Периферия (хотя, безусловно, столица во многом отличается от других регионов) или по традиционно сложившимся трём группам регионов: «западной (приморской), восточной и центральной (с городом Тбилиси - как хозяйственным стержнем» [18, с. 224].

Однако по некоторым показателям заметно формирование статистически значимых различий Север - Юг, при этом следует обратить внимание на то, что как раз южные регионы, не граничащие с Российской Федерацией, демонстрируют к ней большую лояльность, нежели края-соседи. Тем не менее данная гипотеза требует дополнительных проверок на более широкой выборке, учитывающей дифференциацию на более низком уровне административно-территориального деления.

Как уже упоминалось, соцопрос в Грузии является составной частью долгосрочного проекта изучения электоральных процессов, происходящих на протяжении последних десятилетий в соседних с Россией государствах. Более года назад на практически аналогичные вопросы было предложено ответить жителям Белоруссии с целью выявления территориальной дифференциации общественного мнения. Результаты были опубликованы в конце 2020 г. [22]. Сопоставление мнений жителей ближайших соседей по отношению к России представляется дальнейшей исследовательской задачей.

\section{Ссылки / References}

1. Баум В. В., Дегтерёв Д. А., Зябкина Е. И. Десять лет без дипломатического признания: прикладной анализ российско-грузинских отношений (2008-2018 гг.) // Проблемы национальной стратегии. 2019. № 4 (55). С. 70-86.

2. Понамарёва А. М. Репрезентация образа России в политике идентичности властных элит постсоветской Грузии // Южно-российский журнал социальных наук. 2019. Т. 20. № 3. C. 106-126.

3. ЕСПЧ вынес вердикт по иску Грузии к России о нарушениях прав человека в войне 2008 года // Ведомости. 21.01.2021. URL:

https://www.vedomosti.ru/politics/articles/2021/01/21/855017-espch-verdikt (дата обращения: 13.02.2021).

4. Торжество, ложь и безразличие. Как Грузия и Россия восприняли решение ЕСПЧ по делу о войне 2008 года // Кавказ. Реалии. 27.01.2021. URL:

https://www.kavkazr.com/a/31063640.html (дата обращения: 13.02.2021).

5. Силаев Н. Ю. Двадцать лет расходящимся курсом // Россия в глобальной политике. 2009. Т. 7. № 5. C. 103-114.

6. Маркедонов С. «Знаковая отставка»: что стоит за уходом Иванишвили из грузинской политики // Евразия Эксперт. 14.01.2021. URL: https://eurasia.expert/chto-stoit-zaukhodom-ivanishvili-iz-gruzinskoy-politiki/ (дата обращения: 10.02.2021).

7. Маркедонов С. «Третий региональный порядок»: как изменились политические расклады в Закавказье в 2020 году // Евразия Эксперт. 28.12.2020. URL: https://eurasia.expert/kak-izmenilis-politicheskie-rasklady-v-zakavkaze-v-2020/ (дата обращения 10.02.2020). 
8. Силаев Н. Ю. Пределы нормализации: российско-грузинские отношения после парламентских выборов в Грузии // Международная аналитика. 2016. № 3 (17). C. 7-14.

9. Муханов В. М., Скаков А. Ю. Политическая стабильность по-грузински (Грузия после выборов 2016 г.) // Мировая экономика и международные отношения. 2018. Т. 62. № 1. С. 53-62.

10. Выборы в Грузии 2020: третий срок, смена власти или политический кризис // ИНОСМИ.РУ. URL: https://inosmi.ru/social/20201101/248445729.html (дата обращения: 10.02.2021).

11. Мансуров Т. 3. Российско-грузинский диалог о нормализации отношений: ограничения и сферы взаимодействия // Вестник Воронежского государственного университета. Серия: История. Политология. Социология. 2016. № 3. С. 30-36.

12. Айвазян А. С. Грузия: внешняя политика малого государства // Современная Европа. 2020. № 1 (94). C. 80-91.

13. Мосаки Н. Предварительные итоги переписи населения в Грузии: население Грузии составляет лишь 3,7 млн. человек // Демоскоп weekly. № 661-662. 02-15.11.2015. URL: http://www.demoscope.ru/weekly/2015/0661/analit05.php (дата обращения: 12.02.2021).

14. Хатуашвили Х. О. Цивилизационный выбор Грузии // Восточная аналитика. 2018. № 1-2. C. 101-106.

15. Гоциридзе Д. Язык как интеракционное поле в межкультурных отношениях (русский язык в Грузии) // Россия - Грузия. Отношения: энергетика, экономика, безопасность, геополитика, миграция и культура: сборник. Тбилиси, 2018. С. 133-142.

16. Челидзе Н. Миграционные процессы в российско-грузинских отношениях и социальноэкономические последствия // Россия - Грузия. Отношения: энергетика, экономика, безопасность, геополитика, миграция и культура: сборник. Тбилиси, 2018. С. 109-132.

17. Мосаки Н. З. Этническая картина Грузии по результатам переписи 2014 г. // Этнографическое обозрение. 2018. № 1. С. 104-120.

18. Мадры Ц., Качмарек-Кхубнайя Ю. Социально-экономическая регионализация Грузии // Социально-экономическая география. Вестник Ассоциации российских географовобществоведов. 2016. № 5. С. 224-229.

19. Маркедонов С. М. «Грузинский парадокс» в российской политике // Международные процессы. 2003. Т. 1. № 1 (1). С. 116-121.

20. Гамкрелидзе Г. А. Постсоветская Грузия и ее внешняя политика в годы правления Михаила Саакашвили: размышления грузинских интеллектуалов // Интеллигенция и мир. 2017. № 1. С. 129-138.

21. Кошечкина Е. А. Политические и экономические аспекты региональной политики Грузии // Региональные проблемы преобразования экономики: интеграционные процессы и механизмы формирования и социально-экономическая политика региона. Материалы VIII Международной научно-практической конференции. Махачкала, 09-10 октября 2017 г. Махачкала, 2017. С. 168-174.

22. Okunev I. Yu., Shestakova M. N., Bibina E. S. Neighborhood with Russia: implications for regional differentiation of public opinion in Belarus // Russia in Global Affairs. 2020. Vol. 18. № 4 (72). P. 10-36. 